\title{
Nesting behavior of Trypoxylon (Trypargilum) agamemnom Richards (Hymenoptera: Crabronidae)
}

\author{
Buschini, MLT.* and Donatti, AJ. \\ Departamento de Biologia, Universidade Estadual do Centro-Oeste - UNICENTRO, \\ Rua Presidente Zacarias, 875, CEP 85010-990, Guarapuava, PR, Brazil \\ *e-mail: isatunes@yahoo.com.br
}

Received February 16, 2011 - Accepted April 13, 2011 - Distributed May 31, 2012

(With 4 figures)

\begin{abstract}
Nesting behaviour is extremely diversified among solitary nesting sphecids. Thus, the aim of this study was to describe the nesting behaviour of Trypoxylon agamemnon and discuss the advantages of guarding behaviour of males. It was conducted in the Parque Municipal das Araucárias, Guarapuava (PR), Brazil from October/2003 to July/2007. To describe the behaviour of T. agamemnon and construct its ethogram, daily observations were made, totalling 410:19 hours observation. Although the males of T. agamemnon stand guard close to the entrance of the nests, we concluded that this behaviour is not ensuring the protection of nests against parasitoids and that, probably, this behaviour ensures them the paternity, but further studies with microsatellite markers will be necessary to confirm this hypothesis.
\end{abstract}

Keywords: Crabronidae, Hymenoptera, life span, nesting behaviour, Trypoxyon.

\section{Comportameno de nidificação de Trypoxylon (Trypargilum) agamemnom Richards (Hymenoptera: Crabronidae)}

\begin{abstract}
Resumo
O comportamento de nidificação é bastante diversificado entre os esfecídeos solitários. Dessa forma, o objetivo deste estudo foi descrever o comportamento de nidificação de Trypoxylon agamemnon, bem como discutir as vantagens do comportamento de guarda dos machos. O estudo foi realizado no Parque Municipal das Araucárias, Guarapuava-PR, Brasil, de outubro de 2003 a julho de 2007. Para descrever o comportamento de T. agamemnon e construir o etograma, foram feitas observações diárias, totalizando 410:19 horas. Embora os machos de T. agamemnon permaneçam constantemente de guarda na entrada do ninho, foi possível concluir que tal comportamento não está promovendo a proteção dos ninhos contra parasitoides e que, provavelmente, sirva para os machos se assegurarem da paternidade; entretanto, estudos com marcadores microssatélites serão necessários para confirmar essa hipótese.
\end{abstract}

Palavras-chave: Crabronidae, Hymenoptera, tempo de vida, comportamento de nidificação, Trypoxyon.

\section{Introduction}

Nesting behaviour is extremely diversified among solitary nesting sphecids, a group including both Crabronidae and Sphecidae wasps, varying in shape, construction sequence, hunting and provisioning as well as in oviposition (Bohart and Menke, 1976; Amarante, 1999). Most wasps belonging to these families show maternal care in the manner of construction and provisioning of a nest, in which immatures develop to adult stages. The female's time and energy are invested in these activities and, consequently, their reproductive lives revolve around them (Melo, 2000).

Wasps of the genus Trypoxylon Latreille, 1796, family Crabronidae, are solitary, characterised by the independence of the females in the construction and provisioning of their nests (Michener, 1974). In species that use pre-existing cavities for nesting, the females build their nests out of mud

with one wall in contact with the bottom of the cavity or far away from it. They provision these nests using paralysed spiders in a linear series of cells separated from each other by mud partitions (Camillo et al., 1994). This genus includes approximately 660 species (Hanson and Menke, 1996), distributed within the subgenera Trypargilum Richards, 1934 and Trypoxylon. Species of Trypargilum are restricted to the occidental hemisphere, being found from southern Canada to southern Argentina, with the highest diversity in the neotropics (Bohart and Menke, 1976).

In several species of the subgenus Trypargilum the males show a behaviour pattern uncommon to Hymenoptera, the guarding of the nests. They stand guard at the nests that are being built by the females, close to the entrance, preventing the attack by parasites, males and females of 
the same species or of different ones. In addition to this behaviour, they can also take part in activities such as: modelling of the mud partitions and accommodation of the prey brought by the females. This help can increase the number of nests founded by the females and, consequently, their reproductive success (Brockmann and Grafen, 1989).

Considering that the species of Trypoxylon show diverse behavioural strategies, the study of these behavioural differences could be the key to understanding the origin of paternal care in these insects, and the possible selective pressure responsible for its maintenance (Hook and Matthews, 1980). Thus, the aims of this study were to: describe the behaviour of males and females of Trypoxylon agamemnon during the construction of their nests; estimate the life span of the adult wasps; describe the mating and oviposition behaviours and the interactions of the guarding males with their main parasitoids as well as with satellite males. The advantages of male guarding behaviour are discussed in terms of their effect in reducing the parasitism rate in the nest or in providing them the paternity.

\section{Methods}

\subsection{Study area}

This study was conducted in the Parque Municipal das Araucárias, Guarapuava (PR), southern Brazil (2523' 36" S and $51^{\circ} 27^{\prime} 19^{\prime \prime} \mathrm{W}, 1.200 \mathrm{~m}$ asl). The Park comprises an area of approximately 104 ha, covered by Mixt Ombrophilous Forest $(42.75 \%)$, gallery forests $(10.09 \%)$, fields $(6.8 \%)$, swamps $(7.13 \%)$ and altered areas $(33.23 \%)$.

According to Köepper's climatic classification, Guarapuava is a region of mesothermic, humid and superhumid climate, with no dry season. Summers are cool, with the hottest months showing average temperatures of $22{ }^{\circ} \mathrm{C}$. Frosts are common and often severe during the winter, having an average temperature, in the coldest month, of around $12.0^{\circ} \mathrm{C}$.

\subsection{Sampling}

Sampling of wasps was carried out using wooden trapnests as described in Buschini (2006). They were installed only in forest areas with Araucaria, since Buschini and Farjado (2010) verified the presence of this species only in this habitat.

\subsection{Description of the nesting behaviour}

The wasps found inside the nests were marked with non-toxic ceramic paint. Markings were made with dots on the insects' thorax, using different combinations of numbers and colours.

To describe the behaviour of T. agamemnon and construct its ethogram (Figure 1; Table 1), daily observations were made with an otoscope, using the focal observation technique, from beginning to end of the founding of the nest, from October/2003 to July/2007, totalling 410:19 hours observation. Sexing was done in the field, according to behaviour and activities carried out by each individual, i.e. only females transport mud and spiders while males guard the nests. After they were finished, the nests were taken to the laboratory where they were kept in adequate conditions until the emergence of the adults. Later, the adults were weighed, sexed, marked and released back into the field.

\section{Results}

\subsection{Daily activity}

The beginning of nesting is characterised by the arrival of the male or by the activities carried out by the female. These activities begin between 08:56 AM and 09:56 AM $(\mathrm{N}=5)$ and finish between 06:16 PM and 06:58 PM $(\mathrm{N}=6)$. Only females sleep in the nests. The males leave the nests in the afternoon and return in the morning. Similarly, on rainy days, only the females remain in the nests.

\subsection{Nest selection}

For T. agamemnon it is the female who chooses which nest will be built, pairing with a male only minutes before starting to build the nest. The female enters an empty nest and walks all the way to the bottom, returning with the abdomen facing the entrance, biting the floor and dragging her legs along the lateral walls. She enters and leaves the nest several times. The male arrives and pairs with a female, assuming the guarding of the nest, while the female goes after mud to cover the bottom of the nest and begin its construction $(\mathrm{N}=3)$.

Few times $(\mathrm{N}=13)$, the male was found alone inside the empty nest, without any provision. In 3 nests, the male remained alone for up to 5 days ( $\overline{\mathrm{X}}=3$ days) before starting its provisioning. In the remaining 9 nests, it remained alone for up to 7 days ( $\bar{X}=2.9$ days) inside the empty nests, but these were not provisioned. Only once was a couple found inside a nest, but this was also not provisioned. In this case the male remained in the nest for 9 days.

Each female built 1 to 7 nests $(\bar{X}=1.84 \pm 1.25$, $\mathrm{N}=65$ ) and the time each one took to build each nest varied from 1 to 22 days for those with $0.5 \mathrm{~cm}$ opening diameter ( $\overline{\mathrm{X}}=4.92 \pm 3.42, \mathrm{~N}=74)$ and 1 to 12 days for those with $0.7 \mathrm{~cm}(\bar{X}=5.46 \pm 3.31, N=26)$. During Spring and Summer, the nests are built faster, but as the seasons change, the time spent building the nest increases, thus, during Autumn and Winter the time spent building a nest is higher.

\subsection{Provisioning}

Provisioning of the nest is carried out by the female with the males' help. While the female is out hunting, the male stands guard inside the nest, close to the entrance. The female transports the spider with the first pair of legs and sometimes, depending on the size of the prey, with the second pair as well. When the female returns from the field and lands at the nest entrance, the male puts its head out and touches her antennae and mandibles (Figure 2). He then climbs on top of the female, holding her at the thorax with his first pair of legs. As she enters the nest, the male slides over her body and follows her. Posteriorly, 


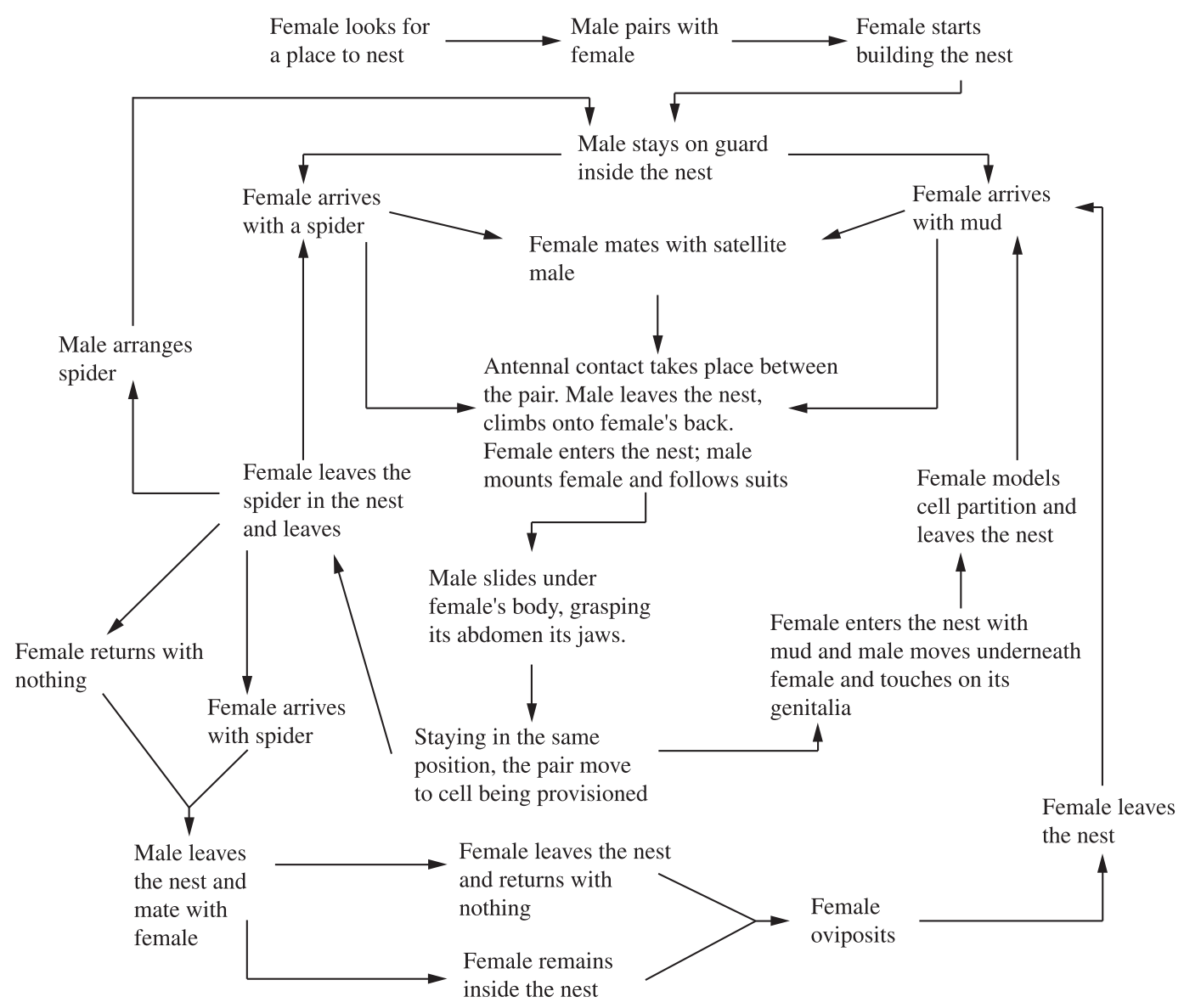

Figure 1. Ethogram of the nesting behaviour of Trypoxylon agamemnon.

Table 1. Average times for the behavioural acts of Trypoxylon agamemnon during nest building.

\begin{tabular}{lccc}
\hline \multicolumn{1}{c}{ Behaviours } & $\begin{array}{c}\text { Average } \\
\text { time }\end{array}$ & $\begin{array}{c}\text { Standard } \\
\text { deviation }\end{array}$ & $\begin{array}{c}\text { Number of } \\
\text { observations }\end{array}$ \\
\hline Transport of mud & $08: 12$ minutes & $04: 08$ minutes & $\mathrm{N}=194$ \\
Female leaves the nest and returns with nothing & $07: 54$ minutes & $12: 16$ minutes & $\mathrm{N}=22$ \\
Transport of spider & $22: 20$ minutes & $14: 55$ minutes & $\mathrm{N}=60$ \\
Female leaves the spider in the nest & $00: 55$ seconds & $00: 27$ seconds & $\mathrm{N}=142$ \\
Male stays on guard and female leaves the mud & $00: 30$ seconds & $00: 16$ seconds & $\mathrm{N}=85$ \\
Mating & $00: 07$ seconds & $00: 02$ seconds & $\mathrm{N}=38$ \\
Male arranges spider & $00: 54$ seconds & $00: 34$ seconds & $\mathrm{N}=75$ \\
Time the female takes to fetch each mud pellet & $03: 15$ minutes & $02: 27$ minutes & $\mathrm{N}=209$ \\
Hug-like position after mating & $00: 54$ seconds & $00: 19$ seconds & $\mathrm{N}=5$ \\
Construction of cell partitions & $01: 15: 00$ hours & 0 & $\mathrm{~N}=2$ \\
Oviposition & $09: 58$ minutes & $01: 01$ minutes & $\mathrm{N}=2$ \\
Female mates with satellite male & $00: 07$ seconds & $00: 01$ seconds & $\mathrm{N}=7$ \\
\hline
\end{tabular}

he places himself under the female, holding her petiole with his mandibles. The pair then walks in this position to the cell that is being provisioned. The male gets out from under the female and, touching her abdomen with his head and legs, returns to the guarding position while the female deposits the spider. The male then accommodates the spider brought by the female. Nevertheless, we observed that in some cases $(\mathrm{N}=11)$ the male does not accommodate the spiders and the task is carried out by the female.

In only 1 case we observed the female return from the field, enter the nest and deposit the prey without the male being present. Nevertheless, when we removed a male for marking the female interrupted her activities. When arriving at the nest, the female landed at the opening and 
waited for the male to touch her antennae. Since he was not there, she left the spider at the entrance of the nest and returned shortly without any prey. She flew around the nest as if looking for the male in other traps. She then returned to the nest and discarded the spider that was at the entrance. Later, she went down to the cell that was being provisioned and displaced all the spiders, assuming the guarding of the nest.

\subsection{Mating}

Ordinarily, mating occurs before oviposition, however there are variations. It always occurs outside the nest and takes an average 7 seconds ( $\mathrm{SE}=2$ seconds, $\mathrm{N}=38$ ). During mating, the female lifts the end of her abdomen while the male curves his down, placing his genitalia in the female (Figure 3). He holds the female's thorax with his legs at the wings.

Sometimes mating occurs when the female returns empty-handed from the field $(\mathrm{N}=11)$. As soon as she arrives, she lands at the entrance of the nest and touches antennae with the male. He places himself on top of her and copulates. To enter the nest, the male slides over the female's body entering immediately behind her. Inside the nest, the male places himself under the female and they remain in a hug-like position ( $\bar{X}=54$ seconds \pm 19 seconds, $\mathrm{N}=5$ ), crossing both abdomens at the petiole. The couple then exits the nest with their abdomens facing the entrance.
Mating also occurred when the female returned from the field with a spider $(\mathrm{N}=21)$. As soon as the female lands close to the nests' entrance, she touches the male's antennae, so that he leaves the nest, mounts her and copulates. The male then slides over the female's body and enters the nest behind her. On only 1 occasion the female left the nest, returned with another spider and copulated again.

\subsection{Oviposition}

The female oviposits after provisioning the cell with the last captured spider, depositing the egg on its abdomen. A few times, oviposition occurred without prior mating $(\mathrm{N}=7)$. While the female is depositing the last spider in the cell, the male stays behind, touching her abdomen with his mandibles. After depositing the spider the female leaves the nest and the male remains to accommodate the spider, later assuming a guarding position. When the female returns, the previously described behaviour is repeated. Inside the nest, the female accommodates the spiders while the male touches her genitalia with his mandibles. In the $0.5 \mathrm{~cm}$ diameter nests, the couple leaves the nest with their abdomens facing the entrance. Outside the nest, the female turns and enters the nest with her abdomen facing the cell. The male enters the nest and facing the female, caresses her $(\bar{X}=1: 00$ minute $\pm 1: 02$ minutes, $N=25)$, i.e., bites her mandibles, head and antennae, while she lays the egg.

Sometimes the female might push the male entering and leaving the nest several times until the moment of

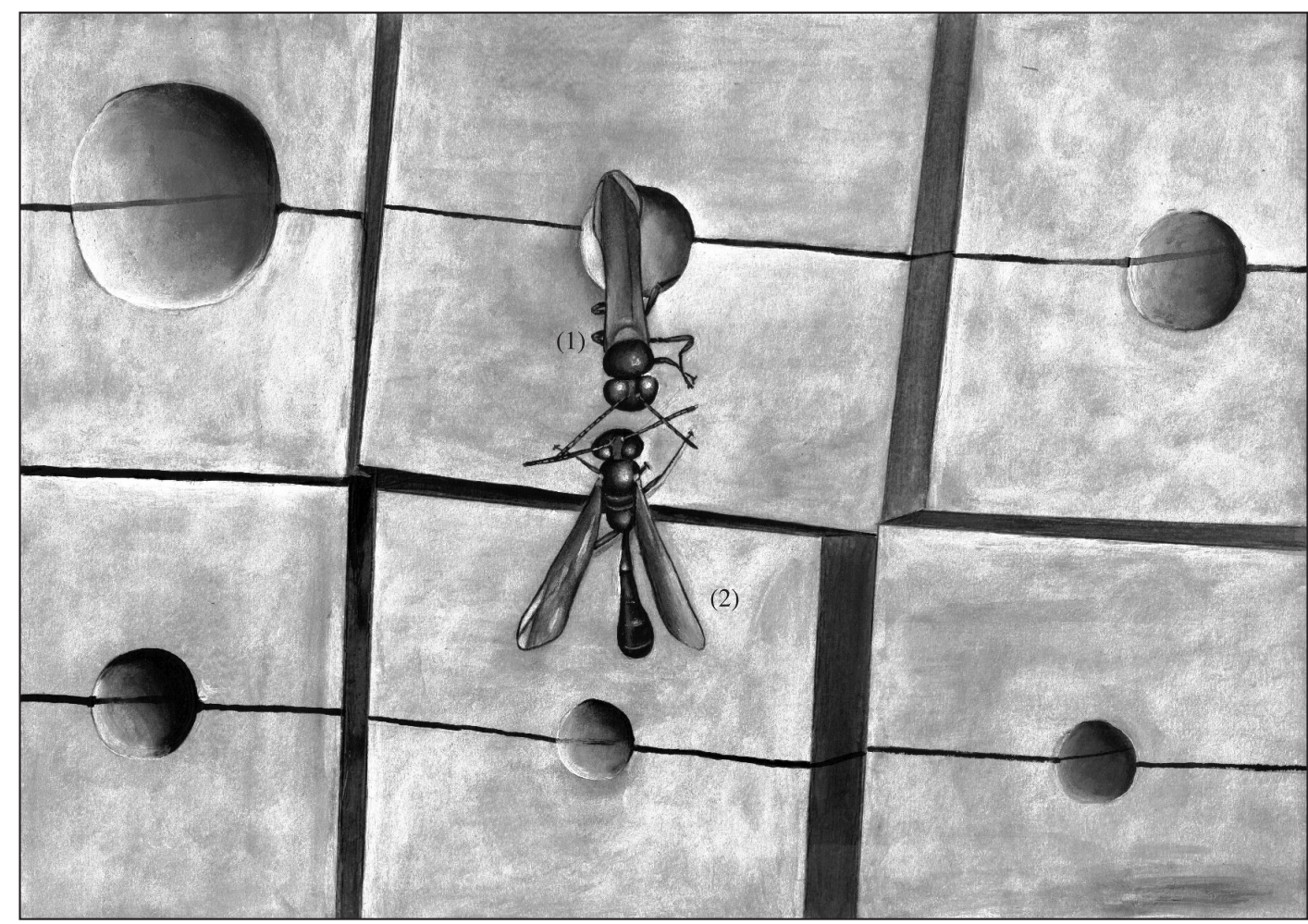

Figure 2. Antennal contact between male (1) and female (2) in trap-nest of $0.7 \mathrm{~cm}$ diameter. (Illustration of Rigon, J.). 


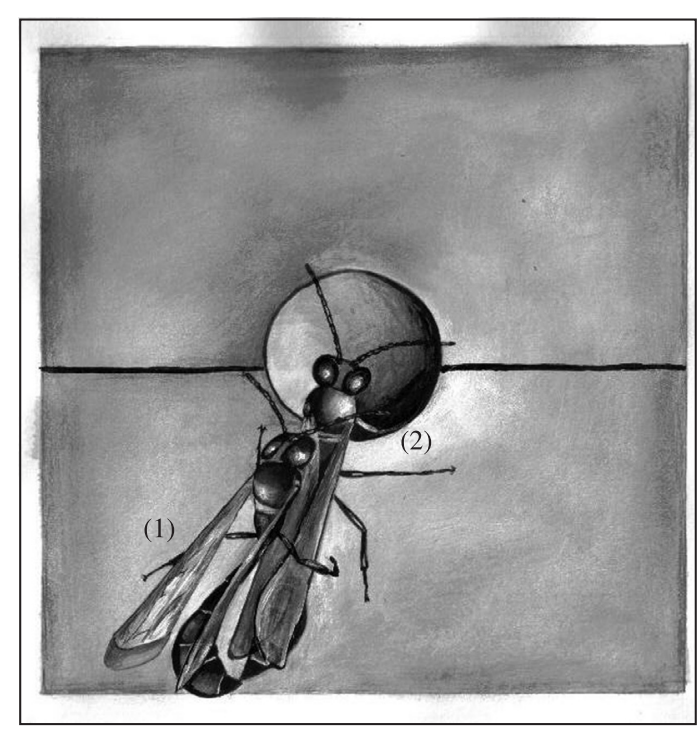

Figure 3. Male (1) leaves the trap-nest of $0.5 \mathrm{~cm}$ diameter and mates with the female (2). (Illustration of Rigon, J.).

oviposition. Later, the male leaves the nest and the female stands guard until he returns. When the male returns to guard the nest, the female goes to collect mud and begins the partitioning of the cell. The only difference in behaviour in nests of larger diameters $(0.7 \mathrm{~cm})$, is that the female shifts position inside the nest, without having to exit. When oviposition occurs immediately after mating $(\mathrm{N}=16)$, the female does not leave the nest, turning inside it, in both 0.5 and 0.7 diameter nests, and faces the male. The male continues to caress her, later assuming the guarding position and turning towards the female every once in a while to caress her while she lays on the nest floor and oviposits. In another observation, after being caressed, the female turns inside the nest and faces the bottom. The male turns as well and lifts the female abdomen with his head. The female then leaves the nest and returns empty handed, landing close to the entrance and repeating the entry behaviour. The male enters behind the female and starts lifting her abdomen with his head. A few times, the female turns towards the male, who then caresses her. He then turns back and assumes the guarding position, while the female oviposits. The average oviposition time was 9:58 minutes ( $\mathrm{SE}=1: 01, \mathrm{~N}=2$ ).

When the nest is being finished, and male and female are provisioning the last cell, there is not enough room for the couple. Thus the female remains in the nest, facing the entrance, while the male stays outside, biting her mandibles and pulling at her antennae. Every now and then the female shifts position, accommodating the spiders while the male bites her abdomen. She then turns and oviposits.

\subsection{Construction of cell partitions}

After oviposition, the female leaves the nest to fetch mud that will be used in the construction of partitions between two cells, or for closing the nest once it is finished. The female transports this mud using her mandibles and first pair of legs, or only the mandibles if the pellet is small enough. When arriving at the nest, the female lands close to the entrance and touches antennae with the male that is standing guard. The behaviour described for each time the female returns to the nest is repeated, whether she is carrying spiders, mud or nothing at all. As soon as she starts placing the mud the male returns to its guarding position. The average time the female took to fetch each mud pellet was 08:12 minutes ( $\mathrm{SE}=4: 08$ seconds, $\mathrm{N}=194$ ) and to build the entire partition $01: 15$ hours $(\mathrm{SE}=0, \mathrm{~N}=2)$, with an average 7.5 trips to collect the mud used for each partition ( $\mathrm{SE}=1.33$ trips, $\mathrm{N}=2$ ).

\subsection{Behaviour of the male towards his natural enemy Chrysididae}

The Chrysididae female lands close to the trap nest's entrance and walks around the opening until she is positioned at the top, in the middle, with her head facing the entrance. While entering, the female places her head inside the nest and slowly slides her body, crawling along the roof so slowly that the guarding male never notices her presence. She then slides between the male's antennae without him noticing her presence. The Chrysididae female takes more time to crawl through the nest than to oviposit. After which, she quickly leaves the nest, crawling along the roof without the male noticing her. This behaviour was observed three times, one of which lasted 21:32 minutes.

In another observation, the male was standing guard and the Chrysididae female entered the nest, crawling along the floor. She passed the male and reached the bottom. The male then pulled the cleptoparasite by the mandibles and legs and sometimes by the antennae, trying to remove it from inside the nest. Both ended up falling to the ground three times but the male of T. agamemnon was faster to return to its guarding position. The female Chrysididae resumed trying to enter the nest but was not successful and gave up. This behaviour lasted 2:30 minutes.

When a guarding male left the nest unattended, a female Chrysididae entered the nest and moved directly towards the cell to lay the egg in 1:28 minutes.

\subsection{Satellite male}

The presence of satellite males was observed for T. agamemnon. They keep circling the areas where there are several nests under construction. When they land, they position themselves close to the nests' entrance and remain with their wings wide open (Figure 4). There are some variations in the behaviour of both the guarding male and the satellite male.

Normally the guarding male does not leave his position even when a satellite male lands close to the nests' entrance. What is frequently observed is the guarding male advancing, with his mandibles, towards the satellite male awaiting the female. Once the female returns with mud or spiders, the satellite male quickly jumps her trying to copulate. A few times, the female flew away $(\mathrm{N}=4)$, but when returning 
ended up copulating with the satellite male, while the guarding male remained in the same position.

Other mating attempts included agonistic interactions. In one of them, as soon as the female arrived, the male that was in the nest climbed on top of her and the satellite male climbed on top of him. Both tried copulating with the female but were unsuccessful. In other attempts $(\mathrm{N}=3)$, as soon as the female returned with the spider, and the satellite male had already climbed on top of her, the guarding male left the nest and flew in the couple's direction, biting the satellite in the thorax and petiole. They both fell to the ground $(\mathrm{N}=1)$, letting go of each other, and the guarding male returns to its position.

The average mating time for satellite males was 7 seconds ( $\mathrm{SE}=00: 01$ seconds, $\mathrm{N}=7$ ).

\subsection{Life span}

Using the mark and recapture technique, although we were not able to determine the adult life span, we were able to observe that they live a relatively long life. One hundred and four males were marked and 36 were recaptured. Of these, seven were observed for another 5 months, one for a year, two months and nine days and one for eleven months and six days. Ninety nine females were also marked and 23 recaptured. Of these, 3 were observed for 7, 8 and 10 months, respectively. Of the remaining marked animals, some were not observed again and some were observed for a few months, weeks or days.
We also observed that wasps that were marked before Winter were recaptured after Winter, suggesting that adult males of Trypoxylon agamemnon spend Winter in diapause. Three males and two females, marked before Winter, were recaptured in Spring. In addition, we observed that although these wasps stopped nesting in 2004, 2005, 2007 in the month of May, and in 2006 in the month of April, in the laboratory they continued to emerge during the month of May $(\mathrm{N}=19)$ and during the month of June $(\mathrm{N}=19)$, even though they were no longer active in the field. No adult was observed spending Winter inside a trap nest.

\subsection{Couple swaps and satellite males}

Twenty four couple swaps were observed, with one female changing males up to five times while provisioning the same nest $(\mathrm{N}=2)$ or when beginning the construction of another $(\mathrm{N}=22)$.

Of a total of 104 marked males, 36 were guarding males, 7 of which were observed as satellites and later as guarding males in a nest. One of them became a satellite during the nest's construction and another assumed the guarding of the nest. Of the 15 males marked as satellites, 4 assumed the guarding of a nest.

\section{Discussion}

As recorded for several species of Trypoxylon (Brockmann, 1980; Coville and Coville, 1980), females of T. agamemnon are responsible for the selection of the orifice in which the nest will be built, although there is

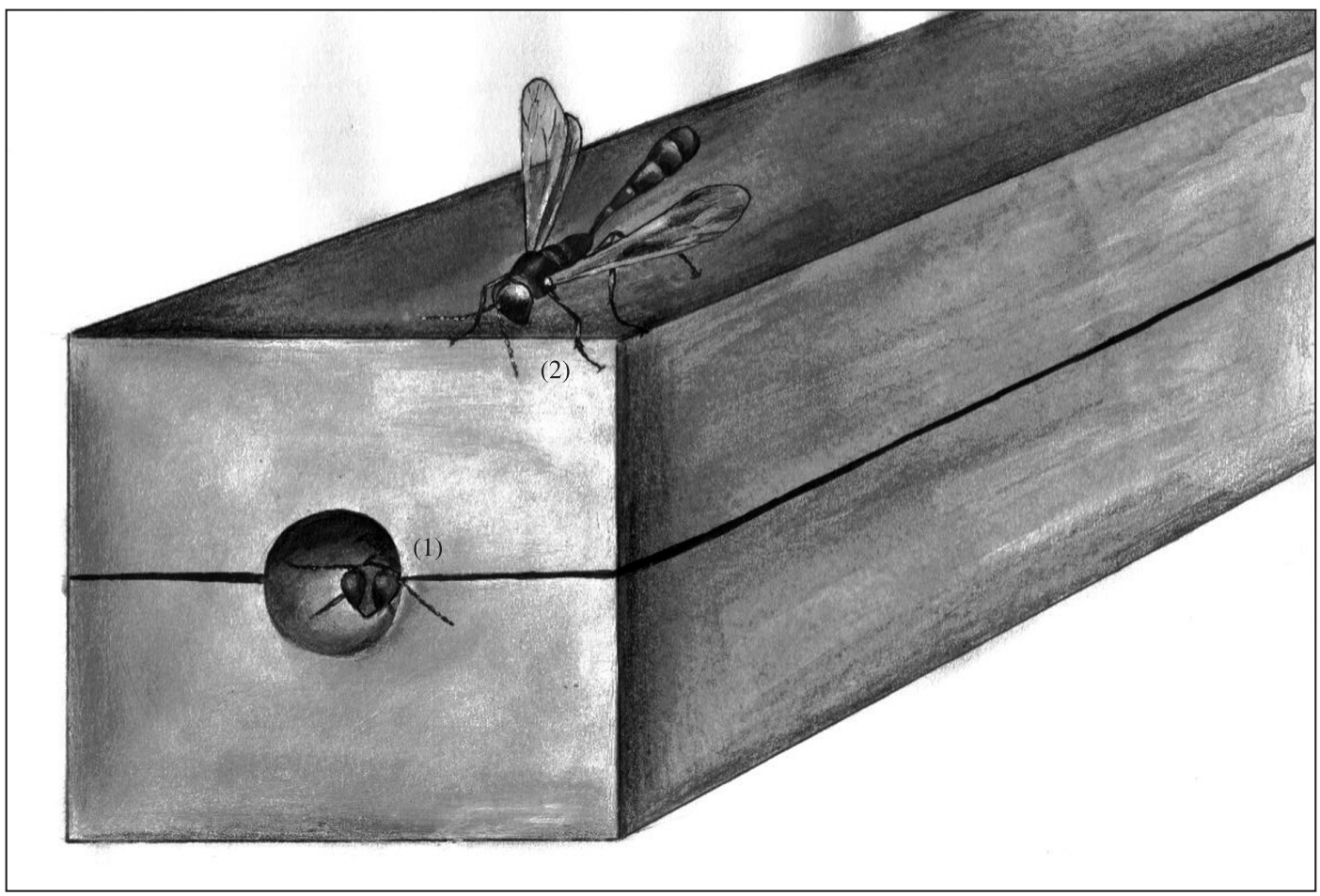

Figure 4. Male on guard inside the trap-nest of $0.5 \mathrm{~cm}$ diameter (1) and satellite male (2). (Illustration of Rigon, J.). 
some variation regarding the size and shape of the selected orifice. Brockmann (1980) observed that when a female of $T$. politum searches for a new site in which to build a nest, she flies over the entire nesting area. On the other hand, according to Coville and Coville (1980), females of Trypoxylon tenoctitlan Richards, 1934 inspect several available cavities and also unoccupied trap-nests before selecting a building site. Since this species uses old or abandoned nests, after selecting a cavity the females remove any remains of cell partitions, cocoons, dead wasps, spiders and larvae. Trypoxylon politum females often select nests that are occupied by other females, and constantly have to fight for the site (Brockmann, 1980). We cannot state that $T$. agamemnon uses old or abandoned nests, because as soon as the nest was built it was removed and taken to the laboratory. What we can state is that this species does not use other wasps' active nests, for this was not observed during the entire study.

After selecting the nest, in many species of the subgenus Trypargilum, male and female unite at the moment, or immediately after, the beginning of the construction of the nest (Coville, 1982). In T. agamemnon this is similar to that observed for T. tenoctitlan (Coville and Coville, 1980), because the female selects the nesting site and pairs with a male at the beginning of the construction of the nest. This behaviour was different for T. rogenhoferi, for which the male stays for a long period of time at the bottom of the cavity, until the female selects a nesting site (Garcia and Adis, 1995). As for T. rogenhoferi (Garcia and Adis, 1995), the male and female of T. agamemnon, that constitute a couple, are capable of recognising each other. According to Amarante (1991) and Coville and Coville (1980) recognition seems to be related to chemical stimuli perceived by touching the antennae.

Different mating situations were observed for T. agamemnon: immediately prior to oviposition, when the female returns empty-handed from the field, and when she returns from the field with a spider and lands at the nest's entrance. Females copulating with satellite males were also observed. All of these situations are different from those reported by Brockmann (1980) for T. politum, because the male copulates with the female not only when she is building the mud tube but also when she is provisioning it or building a cell partition. Brockmann and Grafen (1989) observed, also for $T$. politum, the occurrence of mating immediately after the female places the prey against the bottom of the cell. In T. agamemnon, mating normally occurs after the last spider is accommodated in the cell and always outside the nest, as opposed to T. rogenhoferi (Garcia and Adis, 1995) and Trypoxyon lactitarse Saussure, 1867 (Buschini, unpublished data) for which mating occurs inside the nest. After mating, the female of T. agamemnon finishes provisioning the cell and lays an egg on the abdomen of the last transported prey, as observed for T. rogenhoferi (Garcia and Adis, 1995) and T. vagalum (Coville et al., 2000). For T. tenoctitlan (Coville and Coville, 1980), the egg is also laid at the end of the provisioning process, but it is not necessarily laid on the abdomen of the last transported prey. During oviposition the female of T. agamemnon does not produce any sound, as is the case for males and females of T. monteverdae, that emit a continuous buzz (Brockmann, 1992).

Males of T. agamemnon stand guard during the entire construction of the nest. According to Alcock (1975), the guarding behaviour in "Sphecidae" is a derived form of territoriality, since the nest cavity in a small area is best for defense. On the other hand, Brockmann and Grafen (1989) suggest that the guarding behaviour evolved as a strategy to guarantee mating and, secondarily, acquired a defensive function against conspecific competitors and natural enemies. For Peruquetti and Del Lama (2003) the presence of males in active nests of wasps of the subgenus Trypoxylon is not as frequent as in nests of wasps of the subgenus Trypargilum. Nevertheless, this behaviour was recorded for Trypoxylon (Trypoxylon) fabricator Strand, 1910 (Richards, 1934; Sakagami et al., 1990). These males, as those of Trypoxylon (Trypoxylon) asuncicola Strand, 1910, apparently, do not act as guards, as is the case of Trypoxylon (Trypargilum) (Coville, 1981), being present in nest cavities solely to copulate with the resident females.

A pre-condition to the evolution of the guarding behaviour in male wasps is the male's ability to repel other species of intruding insects, including natural enemies (Lin and Michener, 1972; Peckham et al., 1973). The constant presence of a male guarding the nest during construction was also recorded for several species of the subgenus Trypargilum (Coville and Coville, 1980; Hook, 1984; Brockmann, 1992; Coville et al., 2000) even though Kurczewski (1963) observed that nests of Trypoxylon texense Saussure, 1867 can or cannot be guarded by the male, thus being more exposed to predators, natural enemies or conspecifics. Peckham (1977) showed that the presence of a guarding male significantly increases the survival of the offspring.

Although parental care is rare in Hymenoptera, it is commonly observed in Crabronidae, for which males can participate in other activities such as accommodating prey brought by females, as observed in T. politum (Brockmann and Grafen, 1989), T. tenoctitlan (Coville and Coville, 1980) and T. agamemnon. In T. monteverdae, Brockmann (1992) observed that the male helps the female mold the mud for building the nest. Brockmann (1980) also observed that for T. politum, the male carries out activities that are specifically females', such as spreading the wet mud along the internal wall of the tube with its mandibles and pulling the spiders to the top of the nest. According to Coville and Coville (1980), with this kind of help from the male, the female can spend more time foraging, accumulating more prey in each cell. In species of Trypoxylon (Trypargilum) females are larger than males and are produced in cells with larger quantities of food (Molumby, 1997; Peruquetti and Del Lama, 2003). Molumby (1997). This suggests that sexual dimorphism in these insects could facilitate the evolution of the guarding behaviour in nests of species 
of Trypargilum: the male would "help" his partner better provision the cells in order to produce a female progeny, thus benefiting from this behaviour. Despite the fact that males of T. agamemnon do not help in these activities, the female does not provision the cell without the presence of a male. If the female arrives and the male is not present she begins discarding all provisioned spiders.

In T. agamemnon, we constantly observed satellite males trying to copulate with females as well as the swapping of guarding males and satellite males. This might occur due to the size of the males, as observed by Coville and Coville (1980), with larger males being capable of repelling smaller ones without fighting. Guarding males also repel other males of the same species that are trying to enter the nest, in order to guarantee that the offspring in that nest contains its genes. In addition, repeated mating inside the nest, immediately prior to oviposition, suggests that the guarding behaviour guarantees the paternity of the offspring, reducing the effect of satellite males (Coville, 1982). Coville and Coville (1980) suggest that alternative mating strategies for males of Trypargilum are possible. Thus, males that do not show a guarding behaviour would copulate with the females while they were outside the nests. This behaviour was also observed in T. agamemnon.

According to Alcock (1991), when a female copulates more than once, she enables the competition between the sperm of her partners. Parker (1984) verified that there is sperm competition in insects and that the last male to copulate before oviposition frequently has the advantage of fertilising the eggs. This process is termed sperm precedence and can be observed in most of the studied hemipterans (Michener, 1974). A common tactic is to remain close to the female moments before oviposition and after mating. In this way, the male is capable of repelling possible competing males (Parker, 1984; Alcock, 1983). The direct benefit for the male to stand guard is the reduction of the probability of the female copulating with other males prior to oviposition and thus, cause elimination or dilution of the sperm.

In the study carried out by Santoni (2008) on the average intranidal relationships between species of Trypoxylon, the author states that the presence of the guarding male in most nests seems to guarantee the paternity of the female offspring in species of Trypoxylon. In T. agamemnon, it is possible that the guarding males guarantee the paternity of the offspring. Nevertheless, analysis of the microsatellites is necessary because, according to Peruquetti (2003), for Trypoxylon albitarse and T. rogenhoferi, in most of the nests, paternity of the female progeny is guaranteed by the presence of the guarding male, even though elevated standard deviations regarding relationships were obtained. The author discusses two factors that might reduce family relationships between females born in a same nest: i) more than one female ovipositing in the same nest and ii) multiple matings. Of the two factors discussed by the author only the second would apply to T. agamemnon, since we observed cases of females copulating with satellite males and later with guarding males.

The behaviour of T. agamemnon males towards natural enemies has varied according to the species of parasite, and also amongst the species of Trypoxylon. Garcia and Adis (1995) observed that Chrysididae females waited close to the nests of T. rogenhoferi, entering and depositing their eggs. Sometimes they perforated the walls of the recently built nests, entering and laying their eggs on the provisioned prey. In T. agamemnon we observed a different behaviour, and suggest that this might be a "trade-off" result, involving learning as well. For Jayasingh and Taffe (1982) the cells closest to the nests' entrance present a higher rate of parasitism due to higher exposure and also because parasitoids can oviposit through the closed nest and cell partitions (Coville, 1982). These explanations do not apply to Chrysididae in T. agamemnon nests, since their attacks were random, entering the nests during cell provisioning. Nevertheless, they do apply very well to the attacks by Icheneumonidae, which occurred always in the most external cells (Buschini and Farjado, 2010). Similar results were observed for T. rogenhoferi by Garcia and Adis (1995).

One important result of this study that should be pointed out is relative to the adult life span. We estimate they live much longer than what has been reported in the available literature, for some males were marked and followed for over a year and females for more than 10 months. Coville and Coville (1980), observed that males and of T. tenoctitlan live at least a month, although they did not inform the maximum life span of the adults. Adults of T. politum on the other hand, according to Brockmann and Grafen (1992) live at most a month. With a life span this long, not only juvenile T. agamemnon but also the adults, spend winter in diapause, thus having an overlap of several generations According to Buschini (unpublished data), this is a multivoltine species with an overlap of several generations.

Considering the results presented in this study we can conclude that there are important behavioural differences between the species of Trypoxylon and also between the life span of their adults, whereas in T. agamemnon they spend the winter in diapause and live for about one year. We can also conclude that cleptoparasitoids such as Chrysididae created several strategies to ensure reproductive success in the nests of T. agamemnon, so the guarding behaviour of males is not assuring the protection of nests against them. Probably this male behaviour ensures them the paternity, but further studies with microsatellite markers will be necessary to confirm this hypothesis, whereas females often copulate with male satellites.

Acknowledgements - Partial support was provided by Fundação Araucária (The State of Paraná Research Foundation) and UNICENTRO (Guarapuava - PR, Brazil). We thank Prof. Dr Sérvio Túlio Amarante from the Museu de Zoologia da USP (SP, Brazil) for identifying the wasp. 


\section{References}

AMARANTE, STP., 1991. Biologia e comportamento reprodutivo de Trypoxylon (Trypargilum) albitarse F. (Hymenoptera: Sphecidae). São Paulo: Universidade de São Paulo. Dissertação de Mestrado em Ciências Biológicas.

AMARANTE, STP., 1999. Sphecidae (Hymenoptera). In JOLY, CA. and BICUDO, CEM. (Eds.). Biodiversidade do Estado de São Paulo. Síntese do conhecimento ao final do século XX: Invertebrados Terrestre. São Paulo: FAPESP. p. 183-192.

ALCOCK, J., 1975. Territorial behavior by males of Philanthus multimaculatus (Hymenoptera: Sphecidae). Animal Behaviour, vol. 23, no. 4, p. 889-895. http://dx.doi.org/10.1016/00033472(75)90113-X

-, 1983. Animal behavior, an evolutionary approach. Sunderland: Sinauer.

-, 1991. Adaptive mate-guarding by males of Ontholestes cingulatus (Coleoptera: Staphylinidae). Journal of Insect Behavioral, vol. 4, no. 1, p. 763-771. http://dx.doi.org/10.1007/BF01052230

BOHART, RM. and MENKE, AS., 1976. Sphecidae wasps of the world: a generic revision. California: Berkeley.

BROCKMANN, JH., 1980. Diversity in the nesting behavior of muddaubers Trypoxylon politum SAY (Sphecidae). Florida Entomologist, vol. 63, no. 1, p. 53-64. http://dx.doi.org/10.2307/3494656

-, 1992. Male Behavior, Courtship and Nesting in Trypoxylon (Trypargilum) monteverdeae (Hymenoptera: Sphecidae). Journal of Kansas Entomological Society, vol. 65, no. 1, p. 66-84.

BROCKMANN, JH. and GRAFEN, A., 1989. Mate conflict and male behavior in a solitary wasp, Trypoxylon (Trypargilum) politum (Hymenoptera: Sphecidae). Aminal Behaviour, vol. 37, no. 2, p. 232-255.

-, 1992. Sex ratios and life-history patterns of a solitary wasp, Trypoxylon (Trypargilum) politum (Hymenoptera: Sphecidae). Behavioral Ecology and Sociobiology, vol. 30, no. 1, p. 7-27.

BUSCHINI, MLT., 2006. Species diversity and community structure in trap-nesting bees in Southern Brazil. Apidologie, vol. 37, no. 1, p. 58-66. http://dx.doi.org/10.1051/apido:2005059

BUSCHINI, MLT. and FARJADO, S., 2010. Biology of the solitary wasp Trypoxylon (Trypargilum) agamemnon Richards 1934 (Hymenoptera: Crabronidae) in trap-nests. Acta Zoologica (Stockholm), vol. 91, no. 4, p. 426-432.

CAMILLO, E., GARÓFALO, CA. and SERRANO, JC., 1994. Observações sobre a biologia de Trypoxylon (Trypargilum) rogenhoferi Kohl (Hymenoptera: Sphecidae). Anais da Sociedade Entomológica do Brasil, vol. 23, no. 2, p. 299-310.

COVILLE, RE., 1981. Biological observations on three Trypoxylon wasps in the subgenus Trypargilum from Costa Rica: T. nitidum schultessi, T. saussurei and T. lactitarse (Hymenoptera: Sphecidae). Pan-Pacific Entomologist, vol. 57, no. 2, p.332-340.

-, 1982. Wasps of the genus Trypoxylon subgenus Trypargilum in North America (Hymenoptera: Sphecidae). California: Berkeley.

COVILLE, RE. and COVILLE, PL., 1980. Nesting Biology and Male Behavior of Trypoxylon (Trypargilum) tenoctitlan in Costa Rica (Hymenoptera: Spchecidae). Annals of the Entomological Society of America, vol. 73, no. 1, p. 110-119.
COVILLE, RE., GRISWOLD, C. and COVILLE, PL., 2000. Observations on the Nesting Biology and Behavior of Trypoxylon (Tripargilum) vagulum (Hymenoptera: Sphecidae) in Costa Rica. Pan-Pacific Entomologist, vol. 76, no. 1, p. 28-48.

GARCIA, MVB. and ADIS, J. 1995. Comportamento de Nidificação de Trypoxylon (Trypargilum) rogenhoferi KOHL (Hymenoptera, Sphecidae) em uma floresta inundável de várzea na Amazônia Cetral. Amazoniana, vol. 13, no. 3-4, p. 259-282.

HANSON, PE. and MENKE, AS., 1996. The sphecid wasps (Sphecidae). In HANSON, PE. and GAULD, ID. (Eds.). The Hymenoptera of Costa Rica. New York: Oxford University Press. p. 621-649.

HOOK, AW., 1984. Notes on the nesting and mating behavior of Trypoxylon (Trypargilum) spinosum (Hymenoptera: Sphecidae). Journal of the Kansas Entomological Society, vol. 57, no. 3, p. 534-535.

HOOK, AW. and MATTEWS, RW., 1980. Nesting biology of Oxybelus sericeus with a discussion of nest guarding by male sphecid wasps (Hymenoptera). Psyche, vol. 87, no. 1-2, p. 21-37.

JAYASINGH, DB. and TAFFE, CA., 1982. The biology of the eumenid mud-wasp Pachodynerus nasidens in trap-nests. Ecological Entomology, vol. 7, no. 3, p. 283-289. http://dx.doi. org/10.1111/j.1365-2311.1982.tb00668.x

KURCZEWSKI, FE., 1963. A first Florida record and note on the nesting of Trypoxylon (Trypargilum) texense SAUSSURE (Hymenoptera: Sphecidae). Florida Entomologist, vol. 46, no. 3, p. 243-245. http://dx.doi.org/10.2307/3493335

LIN, N. and MICHENER, CD., 1972. Evolution of sociality in insects. Quartely Review of Biology vol. 47, no. 2, p. 131-59. http://dx.doi.org/10.1086/407216

MELO, G., 2000. Comportamento social em vespas da família Sphecidae (Hymenoptera, Apoidea). In MARTINS, RP., LEWINSOHN, TM. and BARBEITOS, MS. (Eds.). Ecologia e Comportamento de Insetos. Rio de Janeiro: Programa de Pós Graduação em Ecologia do Instituto de Biologia da UFRJ. vol 1., p. 85-130.

MICHENER, CD., 1974. The social behavior of the bees. A comparative study. Cambridge: Harward University Press.

MOLUMBY, A. 1997. Why make daughter larger? Maternal sex-allocation and sex-dependent selection for body size in a mass-provisioning wasp. Trypoxylon politum. Behavioral Ecology, vol. 8, no. 3, p. 279-287. http://dx.doi.org/10.1093/beheco/8.3.279

PARKER, GA., 1984. Sperm competition and the evolution of animal mating strategies. In SMITH, RL. (Ed.). Sperm Competition and the Evolution of Animal Mating Systems. San Diego: Academic Press. p. 1-60.

PECKHAM, DJ., KURCZEWSKI, FE. and PECKHAM, DB., 1973. Nesting behavior of Nearctic species of Oxybelus (Hymenoptera: Sphecidae). Annal of the Entomological Society of America, vol. 66, no. 3, p. 647-661.

PECKHAM, DJ., 1977. Reduction of miltogrammine cleptoparasitism by male Oxybelus subulatus (Hymenoptera: Sphecidae). Annals of the Entomological Society of America, vol. 70, no. 6, p. 823-828.

PERUQUETTI, RC., 2003. Aspectos da biologia, estrutura populacional e parentesco intranidal em vespas do gênero Trypoxylon (Hymenoptera: Sphecidae). São Carlos: Universidade Federal de São Carlos. Tese de Doutorado em Genética e Evolução. 
PERUQUETTI, RC. and DEL LAMA, MA., 2003. Notas sobre a socialidade e a biología de nidificação de Trypoxylon (Trypoxylon) asuncicola Strand, 1910 (Hymenoptera: Sphecidae). Revista Brasileira de Entomologia, vol. 47, no. 4, p. 297-301.

RICHARDS, OW., 1934. The American species of the genus Trypoxylon. Transactions of the Royal Entomological Society of London, vol. 82, no. 2, p. 73-362.
SANTONI, MM., 2008. Biologia de Nidificação e Estrutura Sociogenética Intranidal em Espécies de Trypoxylon (Hymenoptera: Crabronidae). São Carlos: Universidade Federal de São Carlos. Dissertação de Mestrado em Genética e Evolução.

SAKAGAMI, SF., GOBBI, N. and ZUCCHI, R., 1990. Nesting biology of a quasisocial sphecid wasp Trypoxylon fabricator I. Nests and Inhabitants. Japonese Journal of Entomology, vol. 58 , no. 4 , p. 84 